\title{
Effect of planting methods on cane yield, water productivity and economics of spring planted sugarcane (Saccharum officinarum L.) in Ambala (Haryana)
}

\author{
GURU PREM, RAMESH KUMAR, VIKRAM D. SINGH, AMIT KUMAR, RAKESH CHOUDHARY \\ AND AFZAL AHMAD
}

Received : 28.02.2017; Revised : 19.03.2017; Accepted : 27.03.2017

See end of the Paper for authors' affiliation

Correspondence to :

\section{GURU PREM}

Krishi Vigyan Kendra, AMBALA (HARYANA) INDIA Email : gpgrover79@gmail. com
ABSTRACT : An experiment was conducted at farm of Krishi Vigyan Kendra-Ambala to assess the impact of different planting methods of sugarcane i.e. planting methods viz., $\mathrm{T}_{1}$-conventional planting (60 cm row spacing), $\mathrm{T}_{2}$-paired row trench plantation method (60:120 $\mathrm{cm} \mathrm{spacing}$ ) and $\mathrm{T}_{3}-$ paired row ridge and furrow plantation method (100:120 cm spacing) on cane yield, water productivity and economics. The cane yield in conventional planting $\left(\mathrm{T}_{1}\right)$ was $77.53 \mathrm{t} \mathrm{ha}^{-1}, 82.50 \mathrm{t} \mathrm{ha}^{-1}$ in paired row trench plantation technique $\left(\mathrm{T}_{2}\right)$, and $86.20 \mathrm{t} \mathrm{ha}^{-1}$ in paired row ridge and furrow plantation technique $\left(\mathrm{T}_{3}\right)$, which was significantly higher in $\mathrm{T}_{3}$ than in $\left(\mathrm{T}_{1}\right)$ and $\left(\mathrm{T}_{2}\right)$. The water productivity was 2.82 in $\mathrm{T}_{1}, 3.37$ in $\mathrm{T}_{2}$ and 3.79 in $\mathrm{T}_{3}$, respectively. The gross return in farmer practice, paired row

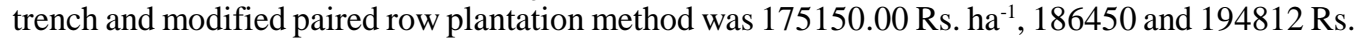
$\mathrm{ha}^{-1}$, respectively. Simultaneously, the BCR was high in paired row trench plantation (2.70) and paired row ridge and furrow plantation method (2.90) than 2.30 in conventional planting.

- KEY WORDS : Sugarcane planting methods, Yield, Water productivity, Economics

-HOW TO CITE THIS PAPER : Prem, Guru, Kumar, Ramesh, Singh, Vikram D., Kumar, Amit, Choudhary, Rakesh and Ahmad, Afzal (2017). Effect of planting methods on cane yield, water productivity and economics of spring planted sugarcane (Saccharum officinarum L.) in Ambala (Haryana). Internat. J. Agric. Engg., 10(1) : 186-190, DOI: 10.15740/HAS/IJAE/10.1/186-190. 